\title{
Identification of ID2 associated with invasion of hepatitis C virus-related hepatocellular carcinoma by gene expression profile
}

\author{
RYOUICHI TSUNEDOMI ${ }^{1,3}$, NORIO IIZUKA ${ }^{1,2}$, HISAFUMI YAMADA-OKABE ${ }^{4}$, TAKAO TAMESA ${ }^{1}$, \\ TOSHIMASA OKADA ${ }^{1}$, KAZUHIKO SAKAMOTO ${ }^{1}$, MOTONARI TAKASHIMA ${ }^{1}$, \\ TAKESHI HAMAGUCHI ${ }^{1}$, TAKANOBU MIYAMOTO ${ }^{5}$, SHUNJI UCHIMURA ${ }^{5}$, \\ YOSHIHIKO HAMAMOTO $^{5}$, MAMORU YAMADA ${ }^{6}$ and MASAAKI OKA ${ }^{1}$
}

\begin{abstract}
${ }^{1}$ Departments of Digestive Surgery and Surgical Oncology, ${ }^{2}$ Bioregulatory Function, Yamaguchi University School of Medicine, 1-1-1 Minami-Kogushi, Ube, Yamaguchi 755-8505; ${ }^{3}$ Research Fellowships of the Japan Society for the Promotion of Science for Young Scientists; ${ }^{4}$ Pharmaceutical Research Department 4, Kamakura Research Laboratories, Chugai Pharmaceutical Co., Ltd., 200 Kajiwara, Kamakura, Kanagawa 247-8530; ${ }^{5}$ Department of Computer Science and Systems Engineering, Faculty of Engineering, Yamaguchi University, 2-16-1 Tokiwadai, Ube, Yamaguchi 755-8611;

${ }^{6}$ Department of Biological Chemistry, Faculty of Agriculture, Yamaguchi University, Yamaguchi 753-8515, Japan
\end{abstract}

Received May 22, 2006; Accepted July 31, 2006

\begin{abstract}
Portal vein invasion (PVI) is a hallmark of metastatic potential of hepatocellular carcinoma (HCC) and is frequently found at a stage of moderately differentiated HCC. To identify genes involved in PVI of HCC associated with hepatitis $\mathrm{C}$ virus (HCV), we performed a comprehensive analysis of 12,600 genes in 35 moderately differentiated HCV-related HCCs by DNA microarray. Our supervised learning method identified 35 genes involved in PVI. Among the 35 identified genes, we focused on the inhibitor of DNA binding 2 (ID2), because it encodes a liver-rich dominantnegative helix-loop-helix protein. The microarray results for ID2 were reproduced by quantitative real-time reverse transcription (QRT)-PCR and Western blot analyses. In an independent set of HCV-related HCCs $(n=28)$ and HCVunrelated HCCs $(n=14)$, our QRT-PCR showed that decrease in ID2 mRNA levels were associated with PVI in HCVrelated $\mathrm{HCC}$ but not $\mathrm{HCV}$-unrelated $\mathrm{HCC}$. In conclusion, our results strongly suggest that $I D 2$ plays an important role in PVI process of HCV-related HCC.
\end{abstract}

\section{Introduction}

Hepatocellular carcinoma (HCC) is one of the most lethal malignancies $(1,2)$. The poor prognosis of HCC can be explained largely by the high rate of intrahepatic recurrences

Correspondence to: Dr Masaaki Oka, Departments of Digestive Surgery and Surgical Oncology, Yamaguchi University School of Medicine, 1-1-1 Minami-Kogushi, Ube, Yamaguchi 755-8505, Japan E-mail: 2geka-1@po.cc.yamaguchi-u.ac.jp

Key words: hepatocellular carcinoma, portal vein invasion, hepatitis $\mathrm{C}$ virus, inhibitor of DNA binding 2 attributable to intrahepatic dissemination of tumor cells (3). Among many factors responsible for intrahepatic recurrence, venous invasion, particularly portal vein invasion (PVI), is one of the most relevant pathologic factors (4). Identification of key genes involved in PVI will allow for improved treatment of HCC.

Since its initial application to clinical science (5), DNA microarray technology has served as a promising tool for elucidation of molecular features of $\operatorname{HCC}(6,7)$. Therefore, it may be useful for identifying key genes involved in PVI. Okabe et al (8) showed that small GTPase-related genes such as RhoGAP8 and ARHGEF6 are preferentially downregulated in HCC with PVI. However, factors such as sample bias may lead to differing results among microarray studies (9). In particular, infection with specific hepatitis viruses can affect HCC gene profiles $(10,11)$. In this regard, the study used cohorts comprising HCC patients infected with different hepatitis viruses (8). To extend the previous finding, it is necessary to profile genes involved in PVI in HCC according to infection with hepatitis $\mathrm{B}$ or $\mathrm{C}$ virus (HBV or $\mathrm{HCV})$.

We recently identified genes related to dedifferentiation of HCV-related HCC (12). Sample rearrangement by molecular profiling showed that moderately differentiated HCCs without PVI were clustered close to well-differentiated $\mathrm{HCC}$, and moderately differentiated HCCs with PVI were clustered close to poorly differentiated HCC. Thus, PVI is induced in moderately differentiated HCC. This result is supported by previous clinicopathologic findings (13). The present study focused on identification of PVI-related genes in $\mathrm{HCV}$-associated, moderately differentiated HCC. We identified 35 PVI-related genes, including inhibitor of DNA binding 2 (ID2), which encodes a dominant-negative helixloop-helix (HLH) protein and is abundant in human liver (14). To our knowledge, this is the first identification of the ID2 in PVI in HCV-related HCC. 
Table I. Clinicopathological features of the 77 HCCs used in this study.

\begin{tabular}{|c|c|c|c|}
\hline & \multirow{2}{*}{$\begin{array}{c}\text { Samples for } \\
\text { DNA microarray } \\
\text { Moderately } \\
\text { differentiated } \\
\text { HCV-related } \\
\text { HCC }(n=35)\end{array}$} & \multicolumn{2}{|c|}{$\begin{array}{l}\text { Independent samples } \\
\text { for QRT-PCR }\end{array}$} \\
\hline & & $\begin{array}{c}\text { Moderately } \\
\text { differentiated } \\
\text { HCV-related } \\
\text { HCC }(n=28)\end{array}$ & $\begin{array}{c}\text { Moderately } \\
\text { differentiated } \\
\text { HCV-unrelated } \\
\text { HCC }(n=14)\end{array}$ \\
\hline \multicolumn{4}{|c|}{ Age (years) } \\
\hline$<50$ & 1 & 0 & 2 \\
\hline$\geq 50$ & 34 & 28 & 12 \\
\hline \multicolumn{4}{|l|}{ Sex } \\
\hline Male & 24 & 22 & 12 \\
\hline Female & 11 & 6 & 2 \\
\hline \multicolumn{4}{|l|}{ PVI } \\
\hline- & 21 & 20 & 7 \\
\hline+ & 14 & 8 & 7 \\
\hline \multicolumn{4}{|l|}{ Size $(\mathrm{cm})$} \\
\hline$<3$ & 10 & 8 & 5 \\
\hline$\geq 3$ & 25 & 20 & 9 \\
\hline \multicolumn{4}{|l|}{ Stage } \\
\hline I & 12 & 9 & 4 \\
\hline I & 18 & 17 & 8 \\
\hline III & 5 & 2 & 2 \\
\hline
\end{tabular}

PVI, portal vein invasion; stage, TNM stage of UICC (2002).

\section{Materials and methods}

Samples for DNA microarray study. We previously pooled oligonucleotide array datasets (huU95A DNA Chips ${ }^{\circledR}$; Affymetrix, Santa Clara, CA) of 76 HCCs (12). Briefly, the specimens obtained at surgery were immediately frozen in liquid nitrogen for RNA extraction. Total RNA was extracted with Sepasol-RNAI (Nacalai Tesque, Tokyo, Japan) and purified with the RNeasy Mini Kit (Qiagen, Tokyo, Japan) according to the manufacturer's instructions. The quality of extracted RNA was confirmed by the appearance of characteristic 28S and 18S rRNA fragments on agarose gels (data not shown). From the above-mentioned datasets, we selected data for 12,600 genes of 35 moderately differentiated HCCs with HCV infection. Clinicopathological features of the 35 HCCs are shown in Table I.

Written informed consent was previously obtained from all patients. The study protocol was approved by the Institutional Review Board for Human Use at Yamaguchi University School of Medicine.

Screening of PVI-related genes by DNA microarray. PVI was histologically diagnosed in $14(40 \%)$ of the 35 HCCs. We used the Fisher ratio $(3,10,12)$ to evaluate the potentials of the selected genes to discriminate between 14 HCCs with PVI and 21 HCCs without PVI. Of 12,600 genes on the DNA microarray, we used 3,559 genes with expression levels $>40$ (arbitrary units by Affymetrix) because we confirmed that genes with expression levels of $\leq 40$ were biologically insignificant in our previous experiment with this-type DNA microarray (15). The 3,559 genes were ranked in order of decreasing magnitude of the Fisher ratio. To determine the number of genes to be considered, a random permutation test was performed as described previously (10). From distribution of the Fisher ratios based on randomized data, all genes that passed the random permutation test $(\mathrm{P}<0.004)$ were selected. Differences in expression levels of 35 genes with Fisher ratios $>1.10$ between HCCs with PVI and HCCs without PVI were statistically significant. The false discovery rate (FDR), i.e., the percentage of genes selected by chance, was calculated as described previously (12) and was $0.08 \%$, validating the gene selection procedure.

Validation of DNA microarray data for ID2 by quantitative real-time $R T$ - $P C R(Q R T-P C R)$. To investigate the reproducibility of ID2 mRNA levels identified by DNA microarray analysis, we used RNA stocks from $22 \mathrm{HCV}$-related HCC samples used in the DNA microarray. Quantitative real-time RT-PCR (QRT-PCR) was performed according to a previously described method (16) with minor modifications. In brief, real-time PCR amplification (LightCycler System Version 3; Roche Diagnostics, Mannheim, Germany) was performed with 10 pmol of each primer sets (ID2-S 5'-GAACTGC AGTTTTAATGGGCAGGAGATGC-3' and ID2-AS 5'-GGA AAGCTTCAGTGCAAGGTAAGTGATGG-3' for ID2; and GAPDH-S 5'-CCTTCATTGACCTCAAC-3' and GAPDHAS 5'-AGTTGTCATGGATGACC-3' for GAPDH) and cDNA equivalent to $10 \mathrm{ng}$ initial RNA. The PCR mixture included $2 \mu 1$ Master Mix (LightCycler FastStart DNA Master SYBR Green I; Roche Diagnostics) and $4 \mathrm{mM} \mathrm{MgCl}_{2}$. Amplification was performed according to a three-step cycle procedure consisting of 40 cycles of denaturation at $95^{\circ} \mathrm{C}$ for $10 \mathrm{sec}$, annealing at $55^{\circ} \mathrm{C}$ for $10 \mathrm{sec}$, and extension at $72^{\circ} \mathrm{C}$ for $20 \mathrm{sec}$. PCR products were quantified with a Lumi-Imager F1 (Roche Diagnostics) and analyzed with LightCycler software (Roche Diagnostics).

We measured quantitatively mRNA levels for ID2 genes using crossing point (CP) and PCR efficiency (E) as described previously (17). The $\mathrm{CP}$ is the number of PCR cycles when maximal acceleration of the fluorescence increase is reached. The investigated transcripts showed PCR efficiencies of 1.69 for GAPDH and 1.75 for ID2. Results, expressed as target gene expression relative to the GAPDH, termed ' $\mathrm{N}_{\text {target }}$, were determined by the formula: $\mathrm{N}_{\text {target }}=\mathrm{E}_{\text {target }}$ [40 (maximal cycle number)CPtarget $/ \mathrm{E}_{\mathrm{GAPDH}}{ }^{\text {[40-CPGAPDH] }}$. The specificity of the products was documented with a gel electrophoresis and analysis of the melting temperature.

Validation of ID2 protein levels by Western blot analysis. Six HCC tissues, which were subjected to the DNA microarray study, were homogenized in lysis buffer containing $50 \mathrm{mM}$ Tris- $\mathrm{HCl}$ (pH 7.5), $165 \mathrm{mM} \mathrm{NaCl}, 1 \mathrm{mM}$ PMSF, $10 \mathrm{mM}$ $\mathrm{NaF}, 10 \mathrm{mM}$ EDTA, $1 \mathrm{mM}$ vanadate, $10 \mu \mathrm{g} / \mathrm{ml}$ aprotinin, $10 \mu \mathrm{g} / \mathrm{ml}$ leupeptin, and $0.1 \% \mathrm{NP}-40$. Protein $(15 \mu \mathrm{g})$ from total cell lysates was fractionated by SDS-PAGE and transferred electrophoretically to PVDF membranes with a Hoefer electrotransfer system (Amersham Biosciences, 


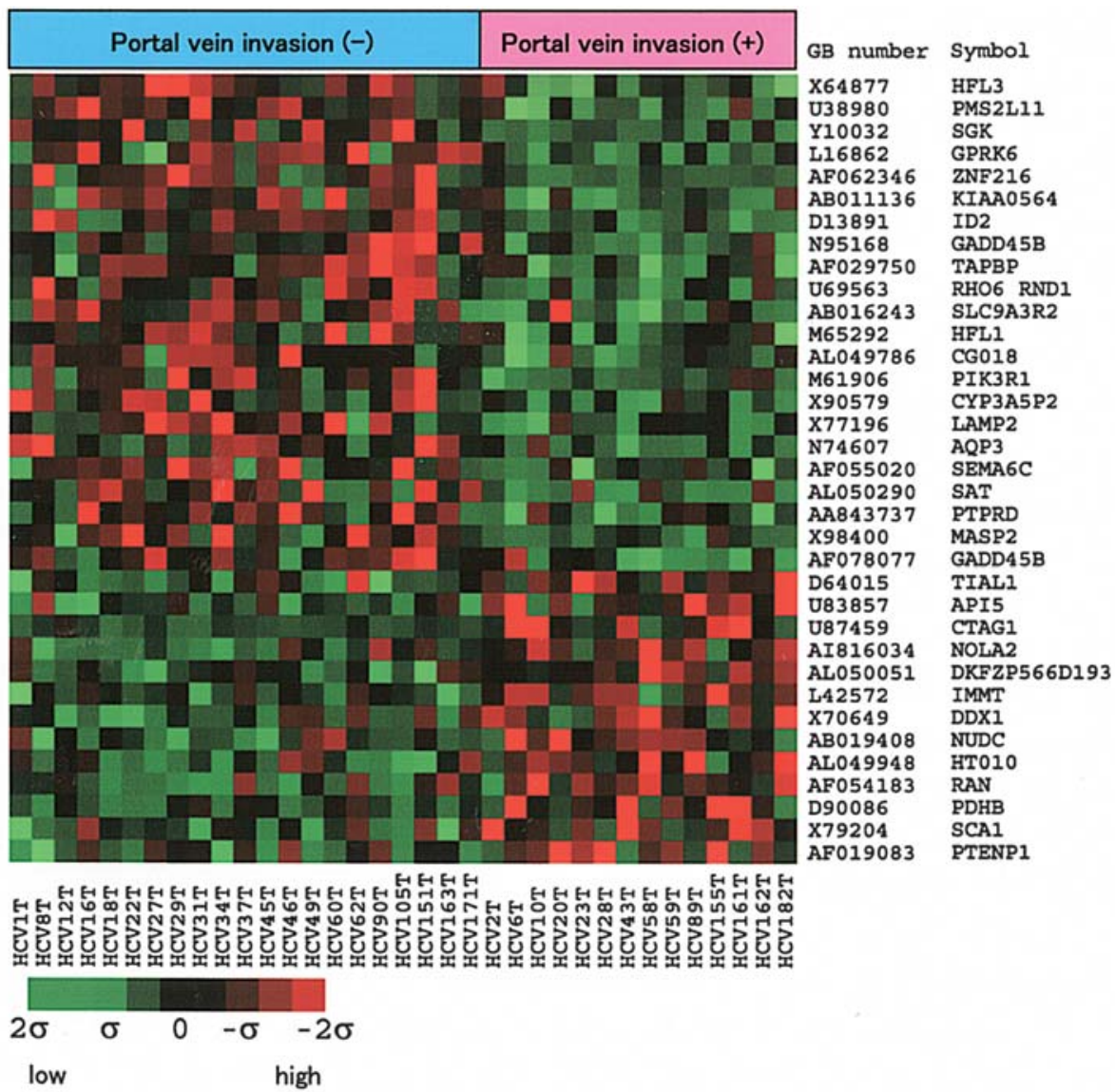

Figure 1. The 35 genes involved in PVI in HCV-related HCC. The top 35 genes were selected by the Fisher ratio and are listed by GenBank accession number and Entrez gene symbol (http://www.ncbi.nih.gov/entrez/query.fcgi?db=gene).

Piscataway, NJ, USA). To detect ID2 and GAPDH protein, membranes were incubated with rabbit polyclonal ID2 (C-20, Santa Cruz Biotechnology, Inc., Santa Cruz, CA, USA) or GAPDH (FL-335, Santa Cruz Biotechnology, Inc.) antibody. Detection was performed with a secondary horseradish peroxidase-conjugated anti-rabbit antibody and the ECL chemiluminescence system (Amersham Biosciences). The mean band densities were determined using NIH Image 1.62 software, and calculated as levels relative to GAPDH.

Assessment of ID2 mRNA levels in an independent set of HCC by $Q R T-P C R$. To investigate the relation among ID2 mRNA levels, PVI, and HCV infection pattern, we examined ID2 mRNA levels in newly enrolled 42 HCCs (Table I) by means of QRT-PCR. Among the 42 patients, 28 were positive for $\mathrm{HCV}$ antibody and the remaining 14 were negative for $\mathrm{HCV}$ antibody. PVI was proven pathologically in $8(28.6 \%)$ of the $28 \mathrm{HCV}$-related HCCs and in $7(50 \%)$ of the $14 \mathrm{HCV}$ unrelated HCCs. Total RNA was extracted from HCC tissues with TRIzol ${ }^{\circledR}$ reagent (Invitrogen Corp., Carlsbad, CA, USA), and $1 \mu \mathrm{g}$ total RNA was reverse-transcribed with $5 \mathrm{U}$ avian myeloblastosis virus reverse transcriptase (Takara Bio Inc., Shiga, Japan) at $45^{\circ} \mathrm{C}$ for $30 \mathrm{~min}$. QRT-PCR procedure was performed as described above. Written informed consent was also obtained from all the 42 patients.

Statistical analysis. Data were presented as mean \pm standard deviation. Significant differences between 2 groups were evaluated by Student's t-test or Mann-Whitney U test. Significant differences between 3 or more groups were evaluated by ANOVA with Scheffe's or Dunnett's test. The Pearson correlation coefficients were calculated for the expression levels of ID2 between DNA microarray and QRTPCR analyses. Calculations were performed with SPSS II software for Windows (SPSS Inc., Chicago, IL). P $<0.05$ was considered statistically significant.

\section{Results}

With our gene selection procedure, 35 genes were identified with expression levels that differed significantly between 14 tumors with PVI and 21 tumors without PVI of the 35 HCV-related HCCs (Fig. 1 and Table II). Among these genes, expression of 13 was up-regulated and that of 22 was down-regulated in HCCs with PVI compared to HCCs without PVI. The 35 PVI-related genes included the gene responsible for apoptosis and stress response ( $S G K, A P I 5$, and $G A D D 45 B)$, cell cycle and cell proliferation $(R A N$ and $N U D C)$, oncogenesis $(D D X 1)$, signal transduction (RHO6), and immune response (TIALI and TAPBP). Thus, the selected genes showed a variety of biological function.

Among the 35 PVI-related genes, we focused on ID2, one of HLH-type transcriptional modulators, because it was shown to encode a liver-rich protein (14). Moreover, another statistical analysis showed that ID2 mRNA levels were significantly lower in HCCs with PVI than in those without 
Table II. Top-35 discriminatory genes in HCC with and without PVI.

\begin{tabular}{|c|c|c|c|c|c|}
\hline $\begin{array}{l}\text { Fisher } \\
\text { ratio }\end{array}$ & GB no. & Description & Symbol & Locus & Function \\
\hline \multicolumn{6}{|c|}{$\begin{array}{l}12 \text { genes up-regulated in HCCs with PVI } \\
\text { in comparison with HCCs without PVI }\end{array}$} \\
\hline 1.496 & U83857 & Apoptosis inhibitor 5 & API5 & $11 \mathrm{p} 12-\mathrm{q} 12$ & Inhibition of apoptosis \\
\hline 1.357 & U87459 & Cancer/testis antigen 1 & CTAG1 & $\mathrm{Xq} 28$ & Tumor antigen \\
\hline 1.342 & AI816034 & Nuclear protein family A, member 2 & NOLA2 & $5 q 35.3$ & $\begin{array}{l}\text { rRNA processing } \\
\text { and midification }\end{array}$ \\
\hline 1.282 & AL050051 & & DKFZP566D193 & $3 q 21.1$ & Unknown \\
\hline 1.248 & L42572 & $\begin{array}{l}\text { Inner membrane protein, } \\
\text { mitochondrial (mitofilin) }\end{array}$ & IMMT & $2 \mathrm{p} 11.2$ & $\begin{array}{l}\text { It interacts with } \\
\text { cytoskeletal components }\end{array}$ \\
\hline 1.159 & X70649 & DEAD/H box polypeptide & $D D X 1$ & $2 \mathrm{p} 24$ & RNA helicase/oncogenesis \\
\hline 1.141 & AB019408 & Nuclear distribution gene $\mathrm{C}$ homologue & $N U D C$ & 1 p35-p34 & Cell proliferation \\
\hline 1.141 & AL049948 & $\begin{array}{l}\text { Uncharacterized hypothalamus } \\
\text { protein HT010 }\end{array}$ & НТ010 & $2 \mathrm{q} 32.2$ & Unclear \\
\hline 1.139 & AF054183 & RAN, member RAS oncogene family & $R A N$ & $6 \mathrm{p} 21$ & Mitosis/cell cycle control \\
\hline 1.132 & D90086 & Pyruvate dehydrogenase (lipoamide) $B$ & $P D H B$ & 3p21.1-p14 & Glucose metabolism \\
\hline 1.118 & X79204 & Spinocerebellar ataxia 1 & SCA1 & $6 \mathrm{p} 23$ & Neuronal transmission \\
\hline 1.102 & AF019083 & $\begin{array}{l}\text { Phosphate and tensin homologue, } \\
\text { pseudogene } 1\end{array}$ & PTENP1 & $9 \mathrm{p} 21$ & Unclear \\
\hline
\end{tabular}

23 genes down-regulated in HCCs with PVI

in comparison with HCCs without PVI

\begin{tabular}{|c|c|c|c|c|c|}
\hline 2.021 & X64877 & $\mathrm{H}$ factor-like 3 & HFL3 & $1 \mathrm{q} 31-\mathrm{q} 32.1$ & Complement activation \\
\hline 1.828 & U38980 & $\begin{array}{l}\text { Postmeiotic segregation } \\
\text { increased 2-like } 11\end{array}$ & PMS2L11 & $7 \mathrm{q}$ & Unclear \\
\hline 1.643 & Y10032 & Seru/glucocorticoid regulated kinase & $S G K$ & $6 q 23$ & $\begin{array}{l}\text { Stress response/ } \\
\text { sodium transport }\end{array}$ \\
\hline 1.587 & L16862 & G protein-coupled receptor kinase & GPRK6 & $5 q 35$ & Signal transduction \\
\hline 1.542 & AF062346 & Zinc finger protein 216 & ZNF216 & $9 q 13-q 21$ & Nucleic acid-binding protein \\
\hline 1.536 & D64015 & $\begin{array}{l}\text { TIA1 cytotoxic granule-associated } \\
\text { RNA binding protein-like } 1\end{array}$ & TIAL1 & $10 \mathrm{q}$ & Immune response \\
\hline 1.477 & AB011136 & & KIAA0564 & $13 q 13.3$ & Unknown \\
\hline 1.406 & D13891 & Inhibitor of DNA binding 2 & ID2 & $2 \mathrm{p} 25$ & $\begin{array}{l}\text { It may negatively regulate } \\
\text { cell differentiation }\end{array}$ \\
\hline 1.368 & N95168 & $\begin{array}{l}\text { GADD45B growth arrest and } \\
\text { DNA-damage-inducible, } \beta\end{array}$ & $G A D D 45 B$ & $19 \mathrm{p} 13.3$ & Stress response/apoptosis \\
\hline 1.345 & AF029750 & TAP binding protein (tapasin) & TAPBP & $6 \mathrm{p} 21.3$ & $\begin{array}{l}\text { Immune response/ } \\
\text { antigen processing }\end{array}$ \\
\hline 1.248 & U69563 & GTP-binding protein RHO6 & RHO6 & $12 q 12-q 13$ & Cytoskelton and cell adhesion \\
\hline 1.234 & AB016243 & $\begin{array}{l}\text { Solute carrier family } 9 \text {, } \\
\text { isoform } 3 \text { regulatory factor } 2\end{array}$ & SLC9A3R2 & $16 \mathrm{p} 13.3$ & Sodium/hydrogen exchanger \\
\hline 1.234 & M65292 & $\mathrm{H}$ factor-like 1 & HFL1 & $1 \mathrm{q} 32$ & Complement activation \\
\hline 1.226 & AL049786 & Hypothetical gene CG018 & $C G 018$ & $13 q 12-q 13$ & Unknown \\
\hline 1.218 & M61906 & $\begin{array}{l}\text { Phosphoinositide-3-kinase, } \\
\text { regulatory subunit, polypeptide } 1\end{array}$ & PIK3RI & $5 q 12-q 13$ & $\begin{array}{l}\text { Signal transduction/ } \\
\text { metabolic actions of insulin }\end{array}$ \\
\hline 1.211 & X90579 & $\begin{array}{l}\text { Cytochrome P } 450 \text {, subfamily IIIA, } \\
\text { polypeptide } 5 \text { pseudogene } 2\end{array}$ & CYP $3 A 5 P 2$ & $7 q 21.3-q 22$ & Detoxification system \\
\hline 1.198 & X77196 & $\begin{array}{l}\text { Lysosomal-associatiated } \\
\text { membrane protein } 2\end{array}$ & $L A M P 2$ & $\mathrm{Xq} 24$ & $\begin{array}{l}\text { Protection, maintenance, } \\
\text { and adhesion of the lysosome }\end{array}$ \\
\hline 1.192 & N74607 & Aquaporin 3 & $A Q P 3$ & $9 \mathrm{p} 13$ & $\begin{array}{l}\text { Molecule transport/ } \\
\text { water channel protein }\end{array}$ \\
\hline 1.186 & AF055020 & Semaphorin Y & SEMA6C & $1 \mathrm{q} 21.2$ & Neural regeneration \\
\hline 1.181 & AL050290 & Spermidine/spermin N1-acetyltransferase & $S A T$ & $\mathrm{Xp} 22.1$ & Polyamine catabolism \\
\hline 1.154 & AA843737 & $\begin{array}{l}\text { Protein tyrosine phosphatase, } \\
\text { reseptor type, D }\end{array}$ & PTPRD & $9 \mathrm{p} 23-\mathrm{q} 24.3$ & Signal transduction \\
\hline 1.149 & X98400 & Mannan-binding lectin serine protease 2 & $M A S P 2$ & 1p36.3-p36.2 & Complement activation \\
\hline 1.140 & AF078077 & $\begin{array}{l}\text { GADD45B growth arrest and } \\
\text { DNA-damage-inducible, } \beta\end{array}$ & $G A D D 45 B$ & $19 \mathrm{p} 13.3$ & Stress response/apoptosis \\
\hline
\end{tabular}




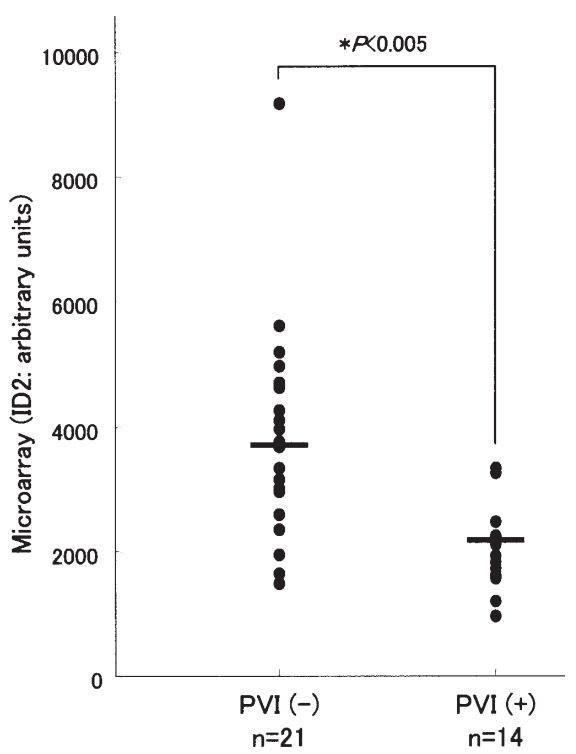

Figure 2. The relation between levels of ID2 mRNA and PVI in HCV-related HCCs. The data for ID2 expression was extracted from DNA microarray dataset of 35 moderately differentiated HCV-related HCCs (HCV-antibody positive). ID2 mRNA levels (mean \pm SD) were $3744.7 \pm 1710.3$ vs $2114.3 \pm 762.8$ in HCCs without PVI $(n=21)$ and HCCs with PVI $(n=14)$, respectively. ID2 mRNA levels were significantly lower in HCCs with PVI than in those without $\left({ }^{*} \mathrm{P}<0.005\right.$ by Student's t-test).

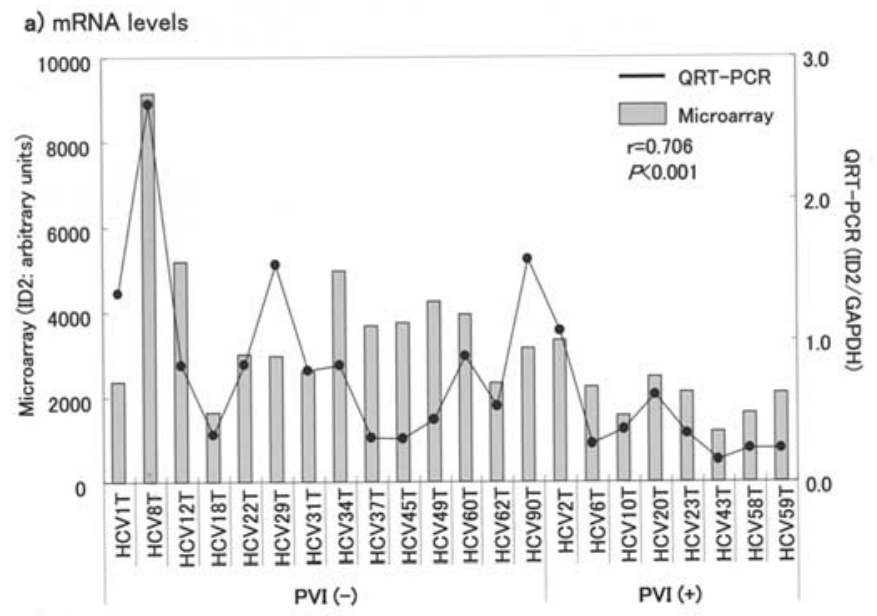

b) protein levels

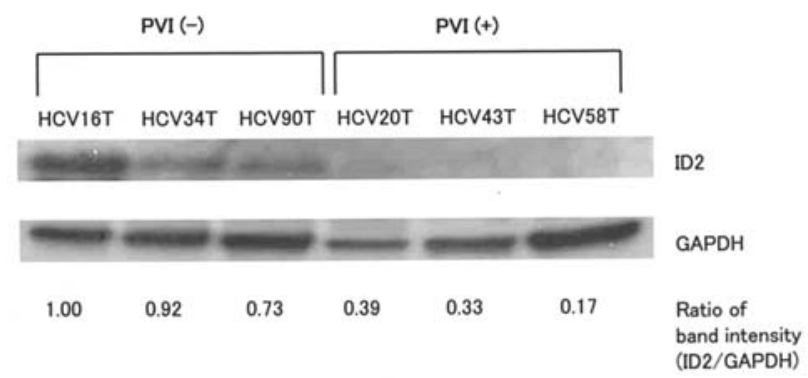

Figure 3. Validation of microarray data for ID2 by quantitative real-time RTPCR and Western blot analyses. (a) ID2 mRNA levels measured by quantitative real-time RT-PCR (QRT-PCR) were calculated relative to those of GAPDH. Note the correlation between the RT-PCR data and the microarray data $(\mathrm{r}=0.71, \mathrm{P}<0.001)$. (b) Western blot analysis showed significantly lower levels of ID2 protein in HCCs with PVI than in those without PVI (mean \pm SD: $0.30 \pm 0.11$ vs $0.88 \pm 0.14, \mathrm{P}<0.005$ ). The band intensity was measured by using $\mathrm{NIH}$ image 1.62 and calculated as levels relative to that of GAPDH.

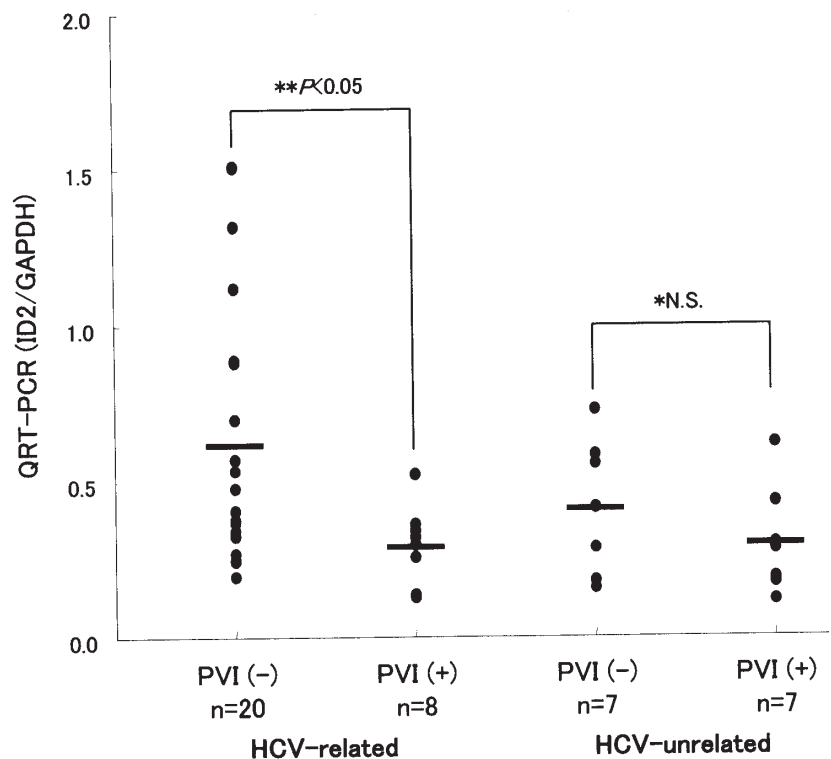

Figure 4. The relation between levels of ID2 mRNA and PVI in HCVrelated and HCV-unrelated HCCs. The data for ID2 expression was extracted from newly enrolled 42 HCCs. We examined the relation between ID2 levels and PVI in two cohorts of 28 moderately differentiated HCV-related $\mathrm{HCCs}$ (HCV-Ab positive) and 14 moderately differentiated HCV-unrelated HCCs (HCV-Ab negative). In $42 \mathrm{HCCs}$, ID2 mRNA levels (mean $\pm \mathrm{SD}$ ) were $0.63 \pm 0.43,0.29 \pm 0.13,0.41 \pm 0.22$, and $0.30 \pm 0.17$ in HCV-related HCCs without PVI (n=21), HCV-related HCCs with PVI $(n=14)$, HCV-unrelated HCCs without PVI $(n=7)$, and HCV-unrelated HCCs with PVI $(n=7)$, respectively. Note that the relation of ID2 levels to PVI is specific to HCVrelated HCC. "Student's t-test; **Mann-Whitney's U test; N.S., not significant.

PVI ( $\mathrm{P}<0.005$ by Student's t-test) (Fig. 2). There was a strong association between ID2 mRNA levels in the microarray data and those in QRT-PCR ( $\mathrm{r}=0.706, \mathrm{P}<0.001)$ (Fig. 3a). Western blot analysis showed that ID2 protein levels were also significantly lower in HCCs with PVI than in those without PVI ( $\mathrm{P}<0.005$ by Student's t-test) (Fig. 3b).

To clarify whether ID2 mRNA levels were associated with PVI in an independent cohort and whether the decrease was specific to HCV-related HCC, we performed QRT-PCR analysis in newly enrolled 42 moderately differentiated $\mathrm{HCCs}$ (28 were HCV-related HCCs and 14 were HCVunrelated HCCs). In $28 \mathrm{HCV}$-related HCCs, ID2 mRNA levels (mean $\pm \mathrm{SD}$ ) were $0.29 \pm 0.13$ and $0.63 \pm 0.43$ in tumors with PVI and those without PVI, respectively. Thus, ID2 mRNA levels were significantly lower in HCV-related HCCs with PVI than in those without PVI $(\mathrm{P}<0.05$ by Mann-Whitney $\mathrm{U}$ test) (Fig. 4). In contrast, there was no statistical difference between ID2 mRNA levels in HCV-unrelated HCCs with PVI and those without PVI (Fig. 4). These results show that decrease in ID2 mRNA levels are associated with PVI in $\mathrm{HCV}$-related HCC, but not HCV-unrelated HCC.

\section{Discussion}

DNA microarray technology allows for analysis of simultaneous expression of thousands of genes and has opened new avenues in molecular medicine (5). Studies with DNA microarray have identified many molecular targets linked to various aspects of $\mathrm{HCC}(8,10-12,18-23)$. Notably, several investigators have used this technology to classify $\mathrm{HCC}$ on 
the basis of clinicopathological behavior such as metastatic potential (23-26). PVI is critical for intrahepatic metastasis of HCC (4); therefore, better understanding of the molecular basis of PVI would help to improve the poor outcome of HCC. However, there have been no DNA microarray studies investigating genes specific for PVI in HCV-related HCC. In the present study, we identified 35 genes linked to PVI in HCV-related HCC without bias among thousands of genes. The most striking finding of our study is that decreased levels of ID2 gene are associated with PVI of HCV-related HCCs but not HCV-unrelated HCCs.

ID proteins are HLH proteins without the basic DNAbinding domain that negatively regulate transcription of target genes by dimerizing with other basic HLH proteins $(25,27,28)$. Many studies have revealed the function of ID proteins as regulators of cell growth and differentiation (27,29-31). Among ID family genes, ID2 is abundant in human liver (14), indicating a significant role of ID2 in hepatocyte differentiation. Our previous study showed that ID2 mRNA levels were lower in HCV-related well-differentiated HCC than in non-tumorous liver, suggesting a role of ID2 in hepatocarcinogenesis induced by HCV (12). Given our present finding that levels of ID2 were significantly decreased in moderately differentiated HCC with PVI compared to those in moderately differentiated HCC without PVI, downregulation of ID2 appears to be linked to tumor progression of HCV-related HCC. A recent report shows that ID2 protein levels decrease in parallel with HCC progression (32). Unfortunately, that study (32) used a cohort consisting of $\mathrm{HBV}$ - and HCV-related HCCs. Our present study not only corroborates the finding (32) but also shows that the role of ID2 is specific for progression of HCV-related HCC.

Other PVI-related genes identified in our study included the gene responsible for apoptosis and stress response ( $S G K$, $A P I 5$, and $G A D D 45 B)$, cell cycle and cell proliferation (RAN and $N U D C)$, oncogenesis $(D D X 1)$, signal transduction (RHO6), and immune response (TIALI and TAPBP). Our previous study showed that $S G K$ was significantly down-regulated in $\mathrm{HCC}$ with PVI and was related to intrahepatic recurrence of HCC (24). The levels of $S G K$ transcript are altered in hepatoma cells in response to osmotic changes or cell volume changes (33); however, it remains unclear how $S G K$ is related to PVI. GADD 45B was found to be down-regulated in HCC by the promoter hypermethylation (34). RHO6, one of Rho GTPase family genes, regulates negatively cell adhesion and the down-regulation of Rho family genes in HCC with PVI was reported in previous microarray study (8). Downregulation of immune response-related genes (TIAL1 and $T A P B P)$ in HCC with PVI is reasonable, because many DNA microarray studies have proposed the significant role of immune response-related genes in HCC progression $(8,22,24,26,35)$. Thus, these genes identified here can be candidates of molecular targets in the treatment of tumor with PVI. Deeper investigation is warranted to disclose their precise action in PVI of HCC.

Our identification of ID2 as a PVI-related gene in HCVrelated $\mathrm{HCC}$ was reproduced by the finding that decreased levels of ID2 mRNA were associated with PVI in independent HCC samples of large size. Genome-wide approaches have attracted a great deal of attention in the field of HCC research.
Many studies (6-12,18-26) have identified genes linked to several clinicopathologic features of HCC. However, there was little overlap between the genes identified in the various DNA microarray studies, and interpretations of the data remain controversial. These inconsistencies may be related closely to differences in sample populations (9). In this regard, our present study adjusted tumor differentiation and hepatitis virus type to avoid a gene-selection bias caused by different sample backgrounds. As a result, we successfully identified ID2 gene in relation to PVI in HCV-related HCC. Our present result also indicates the potential of ID2 as a therapeutic target in the progression of HCV-related HCC but not of HCV-unrelated HCC. Elucidation of the mechanism underlying down-regulation of ID2 in parallel with HCVrelated HCC progression may lead to the use of ID2 as a marker for dedifferentiation of HCV-related HCC.

\section{Acknowledgements}

This work was partly supported by the Venture Business Laboratory of Yamaguchi University, the New Energy and Industrial Technology Development Organization (No. 03A02018a), Ministry of Education, Science, Sports, and Culture of Japan (No. 17591406), and the Japan Society for the Promotion of Science (No. 187616).

\section{References}

1. Thorgeirsson SS and Grisham JW: Molecular pathogenesis of human hepatocellular carcinoma. Nat Genet 31: 339-346, 2002.

2. Llovet JM, Burroughs A and Bruix J: Hepatocellular carcinoma. Lancet 362: 1907-1917, 2003.

3. Bruix J, Boix L, Sala M and Llovet JM: Focus on hepatocellular carcinoma. Cancer Cell 5: 215-219, 2004.

4. Vauthey JN, Lauwers GY, Esnaola NF, et al: Simplified staging for hepatocellular carcinoma. J Clin Oncol 20: 1527-1536, 2002.

5. Schena M, Shalon D, Davis RW and Brown PO: Quantitative monitoring of gene expression patterns with a complementary DNA microarray. Science 270: 467-470, 1995.

6. Lee JS and Thorgeirsson SS: Genome-scale profiling of gene expression in hepatocellular carcinoma: classification, survival prediction, and identification of therapeutic targets. Gastroenterology 127: S51-S55, 2004.

7. Suriawinata $\mathrm{A}$ and $\mathrm{Xu} \mathrm{R}$ : An update on the molecular genetics of hepatocellular carcinoma. Semin Liver Dis 24: 77-88, 2004.

8. Okabe H, Satoh S, Kato T, et al: Genome-wide analysis of gene expression in human hepatocellular carcinomas using cDNA microarray: identification of genes involved in viral carcinogenesis and tumor progression. Cancer Res 61: 2129-2137, 2001.

9. Iizuka N, Hamamoto $\mathrm{Y}$ and Oka M: Predicting individual outcomes in hepatocellular carcinoma. Lancet 364: 1837-1839, 2004.

10. Iizuka N, Oka M, Yamada-Okabe H, et al: Comparison of gene expression profiles between hepatitis B virus- and hepatitis C virus-infected hepatocellular carcinoma by oligonucleotide microarray data based on a supervised learning method. Cancer Res 62: 3939-3944, 2002.

11. Iizuka N, Oka M, Yamada-Okabe H, et al: Differential gene expression in distinct virologic types of hepatocellular carcinoma: association with liver cirrhosis. Oncogene 22: 3007-3014, 2003.

12. Iizuka N, Oka M, Yamada-Okabe H, et al: Self-organizing-mapbased molecular signature representing the development of hepatocellular carcinoma. FEBS Lett 579: 1089-1100, 2005.

13. Kojiro M: Pathological evolution of early hepatocellular carcinoma. Oncology 62 (Suppl 1): 43-47, 2002.

14. Terai S, Aoki H, Ashida K and Thorgeirsson SS: Human homologue of maid: a dominant inhibitory helix-loop-helix protein associated with liver-specific gene expression. Hepatology 32 : 357-366, 2000. 
15. Iizuka N, Oka M, Yamamoto K, et al: Identification of common or distinct genes related to antitumor activities of a medicinal herb and its major component by oligonucleotide microarray. Int J Cancer 107: 666-672, 2003.

16. Iizuka N, Hazama S, Yoshimura K, et al: Anticachectic effects of the natural herb Coptidis rhizoma and berberine on mice bearing colon 26/clone 20 adenocarcinoma. Int J Cancer 99: 286-291, 2002.

17. Neuvians TP, Gashaw I, Sauer CG, et al: Standardization strategy for quantitative PCR in human seminoma and normal testis. J Biotechnol 117: 163-171, 2005.

18. Chuma M, Sakamoto M, Yamazaki K, Ohta T, Ohki M, Asaka M and Hirohashi S: Expression profiling in multistage hepatocarcinogenesis: identification of HSP70 as a molecular marker of early hepatocellular carcinoma. Hepatology 37: 198-207, 2003.

19. Cheung ST, Chen X, Guan XY, et al: Identify metastasisassociated genes in hepatocellular carcinoma through clonality delineation for multinodular tumor. Cancer Res 62: 4711-4721, 2002.

20. Smith MW, Yue ZN, Geiss GK, et al: Identification of novel tumor markers in hepatitis $\mathrm{C}$ virus-associated hepatocellular carcinoma. Cancer Res 63: 859-864, 2003.

21. Neo SY, Leow CK, Vega VB, et al: Identification of discriminators of hepatoma by gene expression profiling using a minimal dataset approach. Hepatology 39: 944-953, 2004.

22. Breuhahn K, Vreden S, Haddad R, et al: Molecular profiling of human hepatocellular carcinoma defines mutually exclusive interferon regulation and insulin-like growth factor II overexpression. Cancer Res 64: 6058-6064, 2004.

23. Ye QH, Qin LX, Forgues M, et al: Predicting hepatitis B virus-positive metastatic hepatocellular carcinomas using gene expression profiling and supervised machine learning. Nat Med 9: 416-423, 2003

24. Iizuka N, Oka M, Yamada-Okabe H, et al: Oligonucleotide microarray for prediction of early intrahepatic recurrence of hepatocellular carcinoma after curative resection. Lancet 361: 923-929, 2003.
25. Lee JS, Chu IS, Heo J, et al: Classification and prediction of survival in hepatocellular carcinoma by gene expression profiling. Hepatology 40: 667-676, 2004.

26. Kurokawa Y, Matoba R, Takemasa I, et al: Molecular-based prediction of early recurrence in hepatocellular carcinoma. $\mathrm{J}$ Hepatol 41: 284-291, 2004.

27. Norton JD: ID helix-loop-helix proteins in cell growth, differentiation and tumorigenesis. J Cell Sci 113: 3897-3905, 2000

28. Benezra R, Davis R, Lockshon D, Turner D and Weintraub H: The protein ID: a negative regulator of helix-loop-helix DNA binding proteins. Cell 61: 49-59, 1990

29. Lasorella A, Uo T and Iavarone A: Id proteins at the cross-road of development and cancer. Oncogene 20: 8326-8333, 2001.

30. Zebedee Z and Hara E: Id proteins in cell cycle control and cellular senescence. Oncogene 20: 8317-8325, 2001.

31. Yokota Y and Mori S: Role of Id family proteins in growth control. J Cell Physiol 190: 21-28, 2002.

32. Damdinsuren B, Nagano H, Kondo M, et al: Expression of Id proteins in human hepatocellular carcinoma: relevance to tumor dedifferentiation. Int J Oncol 26: 319-327, 2005.

33. Waldegger S, Barth P, Raber G and Lang F: Cloning and characterization of a putative human serine/threonine protein kinase transcriptionally modified during anisotonic and isotonic alterations of cell volume. Proc Natl Acad Sci USA 94: 4440-4444, 1997.

34. Qiu W, Zhou B, Zou H, et al: Hypermethylation of growth arrest DNA damage-inducible gene 45 beta promoter in human hepatocellular carcinoma. Am J Pathol 165: 1689-1699, 2004.

35. Matoba K, Iizuka N, Gondo T, et al: Tumor HLA-DR expression linked to early intrahepatic recurrence of hepatocellular carcinoma. Int J Cancer 115: 231-240, 2005. 